\title{
SPEED OF ADJUSTMENT PADA STRUKTUR MODAL: ANALISIS BERDASARKAN SIKLUS HIDUP PERUSAHAAN DI INDONESIA
}

\author{
CICILIA ERNA SUSILAWATI \\ ROSALINA WIJAYANTI \\ CYRILLIUS MARTONO
}

Fakultas Bisnis Unika Widaya Mandala Surabaya, Jl. Kalisari Selatan No.1, Mulyorejo, Surabaya, Indonesia erna-s@ukwms.ac.id

\begin{abstract}
At each stage of the life cycle, companies use different considerations to determine capital structure decisions. This study analyzes differences in company speed of adjustment towards optimal capital structure, based on the company's life cycle in Indonesia. The sample used 74 manufacturing companies from 2013 to 2017. The result is that the maturity company has a greater speed of adjustment than the introduction stage company. While the speed of adjustment at the growth stage there is no difference with the speed of adjustment at the introduction stage. Other findings in this study, the distance between the optimal capital structure and the realized capital structure reduces the difference in speed of adjustment at the maturity and introduction stages. Therefore, the conclusion is the company's life cycle becomes a determinant of capital structure decisions
\end{abstract}

Keywords: Capital structure, speed of adjustment, company's life cycle

Abstrak: Pada setiap tahap siklus hidup, perusahaan menggunakan pertimbangan yang berbeda untuk menentukan keputusan struktur modal. Studi ini menganalisis perbedaan speed of adjustmentperusahaan menuju struktur modal yang optimal, berdasarkan siklus hidup perusahaan di Indonesia. Sampel yang digunakan adalah 74 perusahaan manufaktur dari tahun 2013 hingga 2017. Hasilnya, perusahaan pada tahap maturity memiliki speed of adjustmentlebih besar daripada perusahaan tahap introduction. Sedangkan speed of adjustmentperusahaan tahap gowth tidak ada perbedaan dengan speed adjustment perushaaan pada tahap introduction. Temuan lain dalam penelitian ini, jarak (distance)antara struktur modal optimal dan struktur modal realisasi mengurangi perbedaan speed of adjustmentperusahaan pada tahap maturity dan perusahaan pada tahap introduction. Jadi kesimpulannya adalah siklus hidup perusahaan menjadi faktor pada keputusan struktur modal perusahaan.

Kata kunci: Struktur modal, speed of adjustment, siklus hidup perusahaan

\section{PENDAHULUAN}

Tujuan utama perusahaan adalah memaksimalkan nilai perusahaan. Tujuan tersebut dapat dicapai dengan berbagai cara salah satunya adalah dengan menggunakan struktur modal yang optimal, karena dengan struktur modal yang optimal akan menghasilkan biaya modal (weighted average cost of capital) yang rendah. Oleh karenanya perusahaan akan menyesuaikan struktur modalnya hingga pada titik optimal (Robb dan Robinson 2014). Sementara pada prakteknya struktur modal yang digunakan 
oleh perusahaan (actual capital structure) berbeda dengan struktur modal optimal yang sudah ditentukan sebelumnya. Perbedaan antara struktur modal aktual dan struktur modal optimal ini disebut deviasi atau jarak (distance). Semakin besar jarak struktur modal optimal dengan realisasinya akan memperbesar biaya modal yang harus ditanggung. Perusahaan akan berusaha untuk segera menyesuiakan struktur modalnya menuju struktur modal yang optimal untuk menurunkan biaya modal perusahaan. Kecepatan perusahaan untuk menyesuaikan struktur modal menuju ke struktur modal optimal disebut sebagai speed of adjustment (R. Huang dan Ritter 2009). Dimana konsep kecepatan penyesuaian bermula dari teori trade off dinamis (Abdeljawad et al. 2013). Keputusan untuk melakukan penyesuaian ke struktur modal yang optimal untuk setiap perusahaan berbeda-beda. Adanya perbedaan karakteristik perusahaan, akan menyebabkan perbedaan pada komposisi struktur modal dan keputusan pemenuhan sumber dana perusahaan (G. Huang and Song 2006), (la Rocca et al. 2011).

Salah satu hal yang membedakan keputusan pemenuhan sumber dana adalah tahapan siklus hidup perusahaan. Siklus hidup perusahaan mempengaruhi kebutuhan pendanaan perusahaan, ketersediaan sumber-sumber pendanaan dan berhubungan dengan biaya modal (la Rocca, la Rocca, and Cariola 2011). Tahapan siklus hidup perusahaan memegang peranan yang penting dalam menentukan struktur modal suatu perusahaan (Tian, Han, and Zhang 2015). Perbedaan pengambilan keputusan pendanaan struktur modal bisa berbedabeda tergantung pada siklus hidup perusahaan (Castro et al. 2016). Perusahaan kecil yang baru berdiri cenderung menggunakan modal internal yaitu modal sendiri dari pemilik. Lalu pada saat perusahaan berhasil melewati tahap awal, perusahaan akan cenderung mencari dana pinjaman seperti hutang dagang atau kredit jangka pendek dari bank. Pada tahap pertumbuhan perusahaan akan mengalami masalah likuiditas karena terlalu mengandalkan sumber pembiayaan jangka pendek akibat terbatasnya dana jangka panjang (Anthony dan Ramesh 1992). Pada akhirnya perusahaan akan mengurangi tingkat pertumbuhan sesuai dengan dana internal yang dimiliki atau mencari sumber pendanaan yang lebih elusive seperti venture capital.

Berdasarkan latar belakang tersebut maka, penelitian ini bertujuan untuk mengetahui perbedaan speed of adjustment struktur modal perusahaan pada setiap tahapan siklus hidup perusahaan dan untuk mengetahui pengaruh jarak (distance) antara struktur modal optimal dengan aktualnya terhadap perbedaan speed of adjutment antar tiap tahapan siklus hidup.

\section{Speed of Adjustment Struktur Modal dan Siklus Hidup Perusahaan}

Struktur modal menjadi bagian penting dalam teori keuangan, dimana tingkat penyesuaian perusahaan terhadap struktur modal berdampak pada biaya modal (cost of capital). Struktur modal perusahaan menentukan rata-rata biaya modal tertimbang atau Weighted Average Cost of Capital (WACC), WACC adalah tingkat minimum return yang dibutuhkan dalam investasi perusahaan dan digunakan sebagai discount rate dalam menghitung nilai perusahaan. Perusahaan memilih struktur modal optimal yang meminimalkan biaya modal dengan mempertimbangkan risiko kebangkrutan dan pajak korporasi. Dynamic trade-off theory menyatakan bahwa perusahaan akan melakukan penyesuaian dari waktu ke waktu menuju struktur modal optimalnya (Abdeljawad et al. 2013). Kecepatan perusahaan untuk melakukan penyesuaian 
struktur modal disebut dengan speed of adjustment.

Speed of adjustment yang tinggi, artinya perusahaan cepat menyesuaikan struktur modal aktualnya menuju struktur modal yang optimal. Sebaliknya speed of adjustment yang rendah, menunjukkan bahwa perusahaan lambat dalam melakukan penyesuaian struktur modal aktualnya menuju struktur modal yang optimal. Apabila speed of adjustment pada perusahaan tidak optimal, akan berakibat pada peningkatan adjustment cost (R. Huang and Ritter 2009). Perusahaan yang tidak berada pada posisi speed of adjustment yang optimal, diduga karena perusahaan masih terjebak pada "neutral mutation", yang menurut (MYERS 1984) merupakan kondisi dimana perusahaan terjebak pada pola pendanaan tertentu. Perusahaan akan menuju pada struktur modal yang berada pada titik optimal, namun kondisi struktur modal tersebut selalu berubah dari waktu ke waktu sehingga terdapat jarak di antara struktur modal actual dengan struktur modal optimal (Fischer et al. 1989) dan (Hovakimian et al. 2004). Jarak atau deviasi (distance) antara struktur modal optimal dengan struktur modal aktual akan berdampak pada biaya yang harus ditanggung seperti bankcruptcy cost dan financial distress. Semakin besar jarak antara struktur modal aktual dan struktur modal optimal akan berdampak pada speed of adjustment yang lambat.

Faktor lain yang mempengaruhi speed of adjustment menuju struktur modal optimal adalah siklus hidup perusahaan. Perusahaan akan menyesuaikan struktur modalnya hingga mencapai titik optimal. Penelitian yang dilakukan oleh (Tian et al. 2015) menemukan adanya berbagai variasi yang signifikan terhadap tingkat hutang berdasarkan siklus hidup perusahaan. Menurut (Rhyne dan Brigham 1979) perusahaan pada tahap introduction cenderung menggunakan modal internal yaitu modal sendiri dari pemilik. Lalu pada saat perusahaan berhasil melewati tahap awal, perusahaan akan cenderung mencari dana pinjaman seperti hutang dagang atau kredit jangka pendek dari bank. Pada tahap ini perusahaan belum mampu mendapatkan kepercayaan untuk mendapatkan sumber pendanaan sehingga speed of adjustment menuju struktur modal optimalnya lambat (Castro et al. 2016). Pada tahap growth perusahaan akan mengalami masalah likuiditas karena terlalu mengandalkan sumber pembiayaan jangka pendek akibat terbatasnya dana jangka panjang. Hal tersebut konsiten dengan teori yang dikemukakan oleh (Bulan and Yan 2009) yang menyebutkan bahwa perusahaan pada tahap pertumbuhan memiliki kesempatan investasi yang besar, namun keuntungannya belum mampu untuk memenuhi pendanaan kas internalnya meskipun begitu perusahaan memiliki sumber pendanaan ekternal semakin banyak sehingga memungkinkan perusahaan untuk mendapatkan biaya transaksi yang lebih rendah (Elsas dan Florysiak 2015). Hal ini akan mendorong perusahaan untuk melakukan penyesuaian menuju struktur modal optimal lebih cepat dibandingkan dengan perusahaan yang berada pada tahap introduction. Sedangkan pada tahap mature, profitabilitas dan pertumbuhannya sama, secara sistematik risikonya menurun dan penghasilan kas internal perusahaan meningkat dan memiliki lebih banyak alternatif sumber dana. Perusahaan pada tahap ini juga memiliki cash flow yang lebih stabil dan biaya financial distress rendah serta biaya transaksi semakin kecil sehingga semakin cepat perusahaan melakukan penyesuaian menuju struktur modal optimalnya (Castro et al. 2016).

Kebijakan struktur modal di setiap tahapan siklus hidup perusahaan berbeda karena masing-masing tahapan memiliki karakteristik kebutuhan pendanaan yang berbeda. Hal ini berdampak pada speed of adjustment perusahaan menuju struktur modal optimalnya. Pada tahap introduction 
perusahaan memiliki keterbatasan dalam memperoleh sumber pendanaan, sehingga menyebabkan biaya transaksi yang ditanggung lebih besar. Perusahaan juga belum mampu mendapatkan kepercayaan untuk mendapatkan sumber pendanaan sehingga speed of adjustment menuju struktur modal optimalnya lambat (Castro et al. 2016) Sedangkan pada tahap growth perusahaan mulai memiliki kesempatan investasi yang besar dan pendanaan dari sumber ekternal semakin banyak sehingga memungkinkan perusahaan untuk mendapatkan biaya transaksi yang lebih rendah (Elsas dan Florysiak 2015), hal ini akan mendorong perusahaan untuk melakukan penyesuaian menuju struktur modal optimal lebih cepat dibandingkan dengan perusahaan yang berada pada tahap introduction. Hipotesis yang diajukan adalah:

$\mathrm{H}_{1}$ Speed of adjustment struktur modal pada perusahaan pada tahap growth lebih besar dibandingkan pada perusahaan pada tahap introduction

Pada tahap kedewasaan (mature) perusahaan memiliki lebih banyak alternatif sumber dana. Perusahaan pada tahap ini juga memiliki cash flow yang lebih stabil dan biaya financial distress rendah serta biaya transaksi semakin kecil sehingga semakin cepat perusahaan melakukan penyesuaian menuju struktur modal optimalnya (Castro et al. 2016). Itu berarti perusahaan pada tahap maturity memiliki speed of adjustment yang lebih tinggi dibandingkan dengan perusahaan pada tahap introduction. Hal ini sesuai dengan temuan dari (Bulan and Yan 2009) yang menyatakan bahwa semakin tinggi maturity debt perusahaan semakin cepat dalam melakukan penyesuaian menuju struktur modal optimalnya. Berdasarkan hal tersebut maka diajukan hipotesis:
$\mathrm{H}_{2}$ Speed of adjustment struktur modal pada perusahaan pada tahap maturity lebih besar dibandingkan pada perusahaan pada tahap introduction

Hasil penelitian (DeMarzo dan Sannikov 2006) menunjukkan bahwa perusahaan akan selalu berusaha menuju pada struktur modal yang optimal, tetapi struktur modal yang optimal berubah dari waktu ke waktu sehingga akan menimbulkan perbedaan antara struktur modal aktual dengan struktur modal optimal. Semakin besar jarak (distance) antara struktur modal actual dengan struktur modal optimal akan memperlambat proses penyesuaian menuju struktur modal optimal karena distance yang besar membutuhkan biaya transaksi yang besar juga. Oleh karenanya, faktor distance ini akan memperkecil perbedaan speed of adjustment stuktur modal pada perusahaan pada tahap growth dan maturity dengan perusahaan pada tahap introduction. Hipotesis yang diajukan adalah:

$\mathrm{H}_{3}$ Faktor distance berpengaruh negatif terhadap speed of adjustment struktur modal $\mathrm{H}_{4}$ Faktor distance memperkecil perbedaan speed of adjustment struktur modal perusahaan pada tahap growth dengan tahap introduction

$\mathrm{H}_{5}$ Faktor distance memperkecil perbedaan speed of adjustment struktur modal perusahaan pada tahap maturity dengan tahap introduction.

\section{METODE PENELITIAN}

Populasi yang menjadi obyek penelitian ini adalah seluruh perusahaan yang go publik di Bursa Efek Indonesia, dengan sampel 74 perusahaan yang berada di industri manufaktur yang terdaftar di Bursa Efek Indonesia selama periode 2013 hingga periode 2017. Tabel 1 menunjukkan definisi operasional dan pengkuran variabel yang digunakan dalam penelitian ini. 
Tabel 1 Pengukuran Variabel

\begin{tabular}{|c|c|c|}
\hline Variabel & $\begin{array}{l}\text { Definisi } \\
\text { operasional }\end{array}$ & Rumus \\
\hline $\begin{array}{l}\text { Speed of } \\
\text { adjustment } \\
\text { (SoA) }\end{array}$ & $\begin{array}{l}\text { Lama waktu yang } \\
\text { dibutuhkan untuk } \\
\text { melakukan } \\
\text { penyesuaian } \\
\text { struktur modal } \\
\text { menuju struktur } \\
\text { modal optimalnya }\end{array}$ & $\begin{array}{l}\left(L_{i, t}-L_{i, t-1}\right) /\left(L^{*} i, t-\right. \\
\left.L_{i, t-1}\right)\end{array}$ \\
\hline $\begin{array}{l}\text { Distance } \\
\text { (DIST it) }\end{array}$ & $\begin{array}{l}\text { Jarak struktur } \\
\text { modal aktual } \\
\text { dengan struktur } \\
\text { modal optimal }\end{array}$ & $L^{*} i, t-L i, t-1$ \\
\hline $\begin{array}{l}\text { Leverage } \\
\text { (Lit) }\end{array}$ & $\begin{array}{l}\text { Rasio long term } \\
\text { debt perusahaan } \\
\text { (struktur modal } \\
\text { actual) }\end{array}$ & $\begin{array}{l}\text { Long Term Debt / } \\
\text { Total Assets }\end{array}$ \\
\hline $\begin{array}{l}\text { Leverage } \\
\text { optimal } \\
\left(L^{*} i, t\right)\end{array}$ & $\begin{array}{l}\text { Rasio long term } \\
\text { debt optimal } \\
\text { (struktur modal } \\
\text { optimal) }\end{array}$ & $\begin{array}{l}L^{*} I T=\alpha_{0}+ \\
\beta_{1} \mathrm{ROA}_{I T}+ \\
\beta_{2} \text { Size }_{I T}+ \\
\beta_{3} \text { Growth }_{I T}+ \\
\beta_{4} \text { Tang }_{I T}+ \\
\beta_{5} \text { NDTS }_{I T}\end{array}$ \\
\hline $\begin{array}{l}\text { Tahap } \\
\text { pertumbuhan } \\
\text { (D1) }\end{array}$ & $\begin{array}{l}\text { Perusahaan pada } \\
\text { tahap } \\
\text { pertumbuhan }\end{array}$ & $\begin{array}{l}\text { Sales growth > } \\
\text { median } \\
\text { Capital expediture } \\
>\text { median }\end{array}$ \\
\hline $\begin{array}{l}\text { Tahap } \\
\text { Kedewasaan } \\
(D 2)\end{array}$ & $\begin{array}{l}\text { Perusahaan pada } \\
\text { tahap maturity }\end{array}$ & $\begin{array}{l}\text { Sales Growth } \\
\text { >median } \\
\text { Capita } \\
\text { expenditure < } \\
\text { median }\end{array}$ \\
\hline $\begin{array}{l}\text { Profitabilitas } \\
\text { (ROA) }\end{array}$ & $\begin{array}{l}\text { Rasio tingkat } \\
\text { keuntungan dari } \\
\text { total asset }\end{array}$ & $\begin{array}{l}\text { Net Income/Total } \\
\text { Asset }\end{array}$ \\
\hline $\begin{array}{l}\text { Ukuran } \\
\text { perusahaan } \\
\text { (Size) }\end{array}$ & $\begin{array}{l}\text { natural } \\
\text { logarithm dari } \\
\text { total penjualan }\end{array}$ & Ln (Total Aset) \\
\hline $\begin{array}{l}\text { Pertumbuhan } \\
\text { Perusahaan } \\
\text { (Growth) }\end{array}$ & $\begin{array}{l}\text { Pertumbuhan } \\
\text { Penjualan }\end{array}$ & $\begin{array}{l}(\text { Salest }- \text { salest-1) } \\
\text { Salest-1 }\end{array}$ \\
\hline $\begin{array}{l}\text { Aset tetap } \\
\text { berwujud } \\
\text { (TANG) }\end{array}$ & $\begin{array}{l}\text { Rasio aset } \\
\text { tetap berwujud } \\
\text { dibandingkan } \\
\text { total aset }\end{array}$ & $\begin{array}{l}\text { Fixed Asset /Total } \\
\text { Asset }\end{array}$ \\
\hline
\end{tabular}

\begin{tabular}{lll} 
Non Debt tax & $\begin{array}{l}\text { Perubahan } \\
\text { depresiasi }\end{array}$ & (Depresiasit Depresiasit-1) \\
shield & dibandingkan & Total Asset \\
(NDTS) & & \\
& total aset & \\
\hline
\end{tabular}

Hipotesis penelitian diuji menggunakan persamaan:

SoA $=\alpha_{0}+\beta_{1} D_{1}+\beta_{2} D_{2}+\beta_{3}$ Dist $_{i t}+\beta_{4} D_{1}{ }^{*}$ Distit + $\beta_{5} \mathrm{D}_{2}{ }^{*}$ Distit

Dimana:

SoA : Speed of adjustment

$D_{1} \quad$ : Dummy variabel bernilai 1 untuk perusahaan tahap pertumbuhan dan 0 untuk yang lain

$D_{2} \quad$ : Dummy variabel bernilai 1 untuk perusahaan pada tahap maturity dan 0 untuk yang lain

Dist : Jarak antara struktur modal aktual dengan struktur modal optimal

Alat analisis yang digunakan adalah regresi linier berganda yang diolah menggunakan eviews.

HASIL

Sampel yang digunakan dalam penelitian ini 74 perusahaan yang berada di industri manufaktur. Data yang digunakan berasal dari laporan keuangan dari tahun 2013 hingga tahun 2017 sejumlah 298 data. Data dikelompokkan menurut tahapan siklus hidupnya berdasarkan tingkat pertumbuhan penjualan (sales growth) dan capital expenditure (Anthony and Ramesh 1992). Nilai tengah (median) dari sales growth dan capital expenditure digunakan sebagai batasan dalam menentukan tahapan siklus hidup perusahaan dengan membaginya menjadi empat kuadran seperti ditunjukkan pada figure 1 berikut ini: 


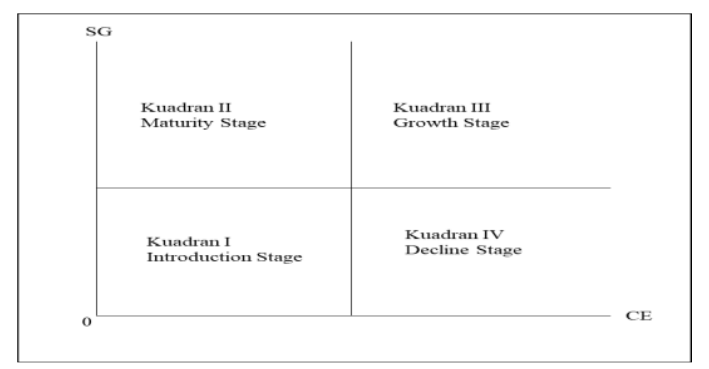

Gambar 1 Kuadran Life Cycle perusahaan

Berdasarkan kriteria diatas, hasil pengelompokkan menunjukkan 24 perusahaan berada pada tahap introduction, 25 perusahaan pada tahap growth dan 26 perusahaan berada pada tahap maturity dan tidak ada perusahaan yang berada pada tahap decline. Selanjutnya perusahaan pada tahap introduction menjadi reference (pembanding) untuk tahapan yang lain. Sedangkan deskripsi data untuk variabel speed of adjustment dan distant dapat dilihat pada tabel berikut:

\section{Tabel 2 Deskripsi data variabel speed of adjustment dan distance}

\section{Std.}

\begin{tabular}{cccccc} 
Var. & Mean & Max. & Min. & Dev. & Obs \\
\hline SoA & 0.132 & 6.345 & -4.171 & 0.792 & 298 \\
DIST & 0.368 & 7.075 & 0.000 & 0.597 & 298 \\
\hline
\end{tabular}

Tabel diatas menunjukkan bahwa rata-rata kecepatan perusahaan dalam melakukan penyesuaian sebesar 0.132. Sedangan jarak antara struktur modal optimal dengan struktur modal actual rata-rata 0.368 dengan nilai maksimal 7.075. Standar deviasi dari kedua variabel berada pada kisaran 0,79 dan 0,59 sehingga hal ini menunjukkan data yang digunakan cukup heterogen.

Berdasarkan hipotesis yang diajukan dan hasil olah data menggunakan metode regresi liner berganda dapat dirangkum pada tabel berikut ini:
Tabel 3 Hasil Olah Data dan Uji Hipotesis

\begin{tabular}{lcccc}
\hline Variabel & Hipotesis & Koefisien & $\begin{array}{c}\text { Prob } \\
(\mathbf{s i g})\end{array}$ & Kesimpulan \\
\hline $\mathrm{D}_{1}$ & + & -0.0429 & 0.751 & Ditolak \\
(growth) & & & & \\
$\mathrm{D}_{2}$ & + & 0.3329 & $0.017^{* *}$ & Diterima \\
(mature) & & & & \\
DIST & - & -0.0314 & 0.730 & Ditolak \\
$\mathrm{D}_{1}{ }^{*} \mathrm{DIST}$ & - & 0.4091 & 0.1162 & Ditolak \\
$\mathrm{D}_{2}{ }^{*} \mathrm{DIST}$ & - & -0.3813 & $0.063^{*}$ & Diterima \\
\hline $\mathrm{R}^{2}$ & & 0.035546 & & \\
Prob F & & $0.059399^{*}$ & & \\
\hline
\end{tabular}

Berdasarkan tabel diatas hasil olah data menghasilkan model fit untuk pengujian hipotesis dengan toleransi kesalahan (a) 10\% dimana nilai $F$ sebesar $5,9 \%$. Selanjutnya model dapat digunakan untuk pengujian hipotesis. Hipotesis pertama menyatakan bahwa Speed of adjustmentstruktur modal pada perusahaan pada tahap growth lebih besar dibandingkan pada perusahaan pada tahap introduction. Hasil pengolahan data menunjukkan bahwa tidak ada perbedaan yang signifikan dalam kecepatan penyesuaian ke struktur modal yang optimal antara perusahaan yang berada pada tahap growth dengan perusahaan pada tahap introduction. Hal ini ditunjukkan dengan nilai probabilitas signifikansi sebesar 0.75 yang lebih besar dari nilai toleransi sebesar $10 \%$. Sehingga hipotesis 1 dari penelitian ini ditolak. Sedangkan untuk hipotesis 2 yang menyatakan bahwa Speed of adjustment struktur modal pada perusahaan pada tahap maturity lebih besar dibandingkan pada perusahaan pada tahap introduction diterima. Tabel 4 menunjukkan bahwa nilai koefisien dari variabel $D_{2}$ sebesar 0,332 dengan probabilitas signifikansi 0,017 lebih kecil dari $a=5 \%$ yang berarti speed of adjustmentperusahaan pada tahap maturity 0,332 lebih besar dibandingkan dengan perusahaan pada tahap introduction.

Hipotesis ketiga menyatakan bahwa faktor distance berpengaruh negatif terhadap speed of adjustmen struktur modal. Hasil pengujian menunjukkan bahwa koefisien variabel Dist sebesar -0,031 dengan tingkat 
probabilitas signifikansi 0,73 yang lebih besar dari $a=10 \%$. Sehingga hipotesis tersebut ditolak. Begitu juga dengan hipotesis 4 yang menyatakan bahwa distance memperkecil perbedaan speed of adjustmentstruktur modal perusahaan pada tahap growth dengan tahap introduction ditolak, karena koefisien yang dihasilkan bernilai positif sebesar 0,409 dengan probababilitas signifikasinya 0,1162 lebih besar dari $a=10 \%$. Artinya faktor distance tidak mempengaruhi perbedaan speed of adjustmentstruktur modal pada perusahaan pada tahap growth dengan tahap introduction. Sedangkan pengujian peran distance pada perbedaan speed of adjustment struktur modal perusahaan tahap maturity dengan tahap introduction menghasilkan koefisien regresi sebesar -0.381 dengan tingakat probabilitas signifikansi 0,063 lebih kecil dari $a=10 \%$. Sehingga hipotesis 5 yang menyatakan distance memperkecil perbedaan speed of adjustmentstruktur modal perusahaan pada tahap maturity dengan tahap introduction diterima.

Berdasarkan pada hasil pengujian hipotesis diatas menunjukkan bahwa tidak ada perbedaan kecepatan perusahaan pada tahap introduction dan tahap growth dalam melakukan penyesuian menuju struktur modal yang optimal. Bahkan jarak antara struktur modal optimal dengan struktur modal actual (distance) tidak menyebabkan speed of adjustment struktur modal pada kedua tahapan tersebut berbeda. Hal ini menunjukkan bahwa pada perusahaan manufaktur di Indonesia biaya transaksi untuk melakukan penyesuaian struktur modal perusahaan pada tahap introduction maupun growth masih cukup tinggi yang disebabkan karena perusahaan belum mampu mendapatkan kepercayaan untuk mendapatkan sumber pendanaan ekternal (Castro et al. 2016). Sedangkan untuk perusahaan pada tahap maturity perusahaan memiliki lebih banyak alternatif sumber dana. Perusahaan pada tahap ini juga memiliki cash flow yang lebih stabil dan biaya financial distress rendah serta biaya transaksi semakin kecil sehingga semakin cepat perusahaan melakukan penyesuaian menuju struktur modal optimalnya (Castro et al. 2016) Itu berarti perusahaan pada tahap maturity memiliki speed of adjustment yang lebih tinggi dibandingkan dengan perusahaan pada tahap introduction. Hal ini sesuai dengan temuan dari (Tian, Han, and Zhang 2015) yang menyatakan bahwa semakin tinggi maturity debt perusahaan semakin cepat dalam melakukan penyesuaian menuju struktur modal optimalnya.

\section{PENUTUP}

Perusahaan pada tahap kedewasaan (maturity) cenderung memiliki speed of adjustmentyang lebih besar dibandingkan dengan perusahaan yang berada pada tahap introduction. Sedangkan speed of adjustment perusahaan pada tahap pertumbuhan (growth) tidak ada perbedaan dengan speed of adjustmentperusahaan pada tahap introduction. Penelitian ini juga menemukan bahwa jarak (distance) antara struktur modal optimal dengan struktur modal realisasi mengurangi perbedaan speed of adjustmentperusahaan pada tahap maturity dengan introduction. Hal ini disebabkan karena perusahaan pada tahap maturity memiliki cash flow yang lebih stabil dan biaya financial distress rendah serta biaya transaksi semakin kecil sehingga memungkinkan perusahaan untuk cepat perusahaan melakukan penyesuaian menuju struktur modal optimalnya. Hasil penelitian ini diharapkan dapat menjadi pertimbangan bagi pengambil keputusan perusahaan dalam menentukan struktur modal. Penelitian selanjutnya disarankan untuk menggunakan sampel yang lebih luas tidak terbatas pada perusahaan yang berada di industri manufaktur agar hasilnya dapat digeneralisasikan. 


\section{REFERENCES:}

Abdeljawad, Islam, Fauzias Mat Nor, Izani Ibrahim, and Ruzita Abdul. 2013. "Dynamic Capital Structure Trade-off Theory : Evidence from Malaysia." Proceedings of 3rd Global Accounting, Finance and Economics Conference 5-7 May 9 (6): 1-10.

Anthony, Joseph H., and K. Ramesh. 1992. "Association between Accounting Performance Measures and Stock Prices. A Test of the Life Cycle Hypothesis." Journal of Accounting and Economics 15 (2-3): 203-27. https://doi.org/10.1016/0165-4101(92)90018-W.

Bulan, L, and Z Yan. 2009. "The Pecking Order of Financing in the Firm's Life Cycle." Banking and Finance Letter 1 (3): $129-40$.

Castro, Paula, María Teresa Tascón Fernández, Borja Amor-Tapia, and Alberto de Miguel. 2016. "Target Leverage and Speed of Adjustment along the Life Cycle of European Listed Firms." BRQ Business Research Quarterly 19 (3): 188-205. https://doi.org/10.1016/j.brq.2016.01.003.

DeMarzo, Peter M., and Yuliy Sannikov. 2006. "Optimal Security Design and Dynamic Capital Structure in a Continuous-Time Agency Model." Journal of Finance 61 (6): 2681-2724. https://doi.org/10.1111/j.15406261.2006.01002.x.

Elsas, Ralf, and David Florysiak. 2015. "Dynamic Capital Structure Adjustment and the Impact of Fractional Dependent Variables." Journal of Financial and Quantitative Analysis. https://doi.org/10.1017/S0022109015000496.

FISCHER, EDWIN O., ROBERT HEINKEL, and JOSEF ZECHNER. 1989. "Dynamic Capital Structure Choice: Theory and Tests." The Journal of Finance. https://doi.org/10.1111/j.1540-6261.1989.tb02402.x.

Hovakimian, Armen, Gayane Hovakimian, and Hassan Tehranian. 2004. "Determinants of Target Capital Structure: The Case of Dual Debt and Equity Issues." Journal of Financial Economics. https://doi.org/10.1016/S0304-405X(03)00181-8.

Huang, Guihai, and Frank M. Song. 2006. "The Determinants of Capital Structure: Evidence from China." China Economic Review 17 (1): 14-36. https://doi.org/10.1016/j.chieco.2005.02.007.

Huang, Rongbing, and Jay R. Ritter. 2009. "Testing Theories of Capital Structure and Estimating the Speed of Adjustment." Journal of Financial and Quantitative Analysis 44 (2): 237-71. https://doi.org/10.1017/S0022109009090152.

MYERS, STEWART C. 1984. "The Capital Structure Puzzle." The Journal of Finance 39 (3): 574-92. https://doi.org/10.1111/j.1540-6261.1984.tb03646.x.

Rhyne, R. Glenn, and Eugene F. Brigham. 1979. "Fundamentals of Financial Management." The Journal of Finance. https://doi.org/10.2307/2327254.

Robb, Alicia M., and David T. Robinson. 2014. "The Capital Structure Decisions of New Firms." Review of Financial Studies 27 (1): 153-79. https://doi.org/10.1093/rfs/hhs072.

Rocca, Maurizio L. la, Tiziana L. la Rocca, and Alfio Cariola. 2011. "Capital Structure Decisions During a Firm's Life Cycle." Small Business Economics 37 (1): 107-30. https://doi.org/10.1007/s11187-009-9229-z.

Tian, Lin, Liang Han, and Song Zhang. 2015. "Business Life Cycle and Capital Structure: Evidence from Chinese Manufacturing Firms." China and World Economy 23 (2): 22-39. https://doi.org/10.1111/cwe.12105. 